African Crop Science Journal by African Crop Science Society is licensed under a Creative Commons Attribution 3.0 Uganda License. Based on a work at www.ajol.info/ and www.bioline.org.br/cs DOI: https://dx.doi.org/10.4314/acsj.v27i4.7

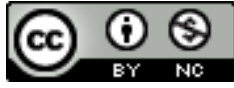

\title{
SCREENING OF COWPEA GERMPLASM FOR RESISTANCE TO Striga gesnerioides IN NIGER
}

\section{SALIFOU, O. SOULEYMANE, M. HAMIDOU, J.B.L.S. TIGNEGRE', P. TONGOONA², S. $\mathrm{OFFEI}^{2}$ and $\mathrm{K}$. $\mathrm{OFORI}^{2}$}

National Agricultural Research Institute of Niger, Tahoua Regional Research Centre, Niger ${ }^{1}$ The world Vegetable Centre, West and Central Africa Samanko research station, Bamako, Mali ${ }^{2}$ West Africa Centre for Crop Improvement, University of Ghana, Accra, Ghana Corresponding author: masalif2000@yahoo.fr

(Received 25 October 2018; accepted 26 November 2019)

\begin{abstract}
The parasitic weed, Striga gesnerioides, is a major constraint to cowpea production in sub-Saharan Africa. It causes significant yield reductions of cowpea, especially in dry areas. The objective of this study was to evaluate the response of 80 genotypes to Striga gesnerioides under natural infestation. The results showed significant variations in the resistance of cowpea lines to Striga; lines IT93K-6932, IT99K-573-1-1 and IT98K-205-8 being free from Striga infestation; while lines 2491-171, 2472-154 and Suvita-2 supported few Striga shoots. The other lines supported more and varied numbers of emerged Striga shoots. The reduction of yield due to Striga infestation was more pronounced for the susceptible genotypes as compared to the resistant and tolerant lines. The high level of resistance observed in some breeding lines can be exploited in breeding cowpea for resistance to Striga. Principal Component Analysis (PCA) and clustering grouped the genotypes in three main clusters as follow: (i) high yielding and tolerant to Striga (ii) moderate yielding and resistant (iii) low-yielding and susceptible.
\end{abstract}

Key Words: Parasitic weed, Striga resistance

\section{RESUME}

L'herbe parasitaire, Striga gesnerioides est une contrainte majeure de la production du niébé en Afrique subsaharienne. Elle cause des réductions de rendement du niébé très importantes dans les zones arides. Un criblage en vue d'évaluer la réaction de 80 génotypes sous infestation naturelle du Striga a été conduit au champ. Les résultats ont montré qu'il y a des différences significatives dans la résistance des lignées du niébé au Striga. Les lignées du niébé IT93K-693-2, IT99K-573-1-1 et IT98K205-8 étaient indemnes de pousses émergées du Striga tandis que les lignées 2491-171, 2472-154 et Suvita-2 ont supporté peu de pousses émergées du Striga. Les autres lignées ont supporté des nombres variés de pousses émergées du Striga. L'effet de l'infestation du Striga a entrainé une réduction du rendement des génotypes sensibles comparés aux résistants et aux tolérants. Le niveau élevé de résistance observé chez certaines lignées peut être exploitée dans l'amélioration de la résistance du 
niébé au Striga. L'analyse du composant principal et la hiérarchisation ont permis de grouper les génotypes en 3 principales grappes comme suit : (i) hautement productriceset tolérantes au Striga (ii) moyennement productrices et résistantes (iii) faiblement productrices et sensibles. 1

Mots Clés: herbe parasitaire, Striga resistance

\section{INTRODUCTION}

Cowpea (Vigna unguiculata (L.)Walp.) is an important source of protein for millions of people worldwide. In sub-Saharan Africa (SSA), cowpea is the most grown legume food crop (Timko et al., 2007; Timko and Singh, 2008). All parts of the plant are consumed by humans and animals. In Niger, cowpea is the major food legume and the second most widely grown crop after pearl millet. It is adapted to a wide range of environments, but various biotic and abiotic constraints reduce its productivity in Sub Saharan Africa (SSA). These constraints include insect pests, diseases, parasitic plants and drought.

Striga gesnerioides (Wild.) Vatke, a parasitic flowering plant is one of the main biotic stresses that challenge cowpea production in drought-prone areas. In Africa, yield reduction caused by $S$. gesnerioides is high $(83-100 \%)$ on susceptible cultivars (Cardwell and Lane, 1995). In Africa five to seven races of Striga have been identified (Botanga and Timko, 2006).

The variability in Striga virulence due to different races, renders the development of resistant varieties very difficult. A number of management approaches for Striga damages are available. These include cultural practices, chemical and biological methods. The most feasible and affordable alternative approach for small-scale farmers is host plant resistance.

Many sources of resistance to the various Striga strains were identified in Africa (Atokple et al., 1995a). Local cultivars with good levels of resistance to race 3 , include TN12180, TN93-80, HTR and introductions such as B301 (Botswana landrace), IT97K-499-38, IT97K-499-35, IT82D-849 are being tested in
Niger. As these introductions often lack farmers' preferred traits and adaptation to local conditions, breeding for resistance should target specific areas and environments. It is, therefore necessary to find new sources of resistance in the local germplasm or to incorporate resistance genes into farmerpreferred varieties.

The Niger national cowpea gene bank has not been screened for Striga resistance, neither have diversity studies conducted on this collection. Research work has mainly focused on testing some improved local materials and introductions, in collaboration with international research institutes such as International Institute of Tropical Agriculture (IITA) and the International Crop Research Institute of Semi-Arid Tropics (ICRISAT). Understanding the diversity among accessions contributes to successful conservation and use of germplasm (Karuri et al., 2010).

A wide genetic base in a germplasm collection provides breeders with important sources of adaptive characters to address climatic and environmental challenges, thus mitigating food insecurity. The objective of the study was to evaluate 80 genotypes mostly from the national cowpea genebank and some introductions for resistance to Striga generioides to identify suitable parents for cowpea improvement.

\section{MATERIALS AND METHODS}

Germplasm. The germplasm used in this study comprised of 80 genotypes that included 68 landraces and 12 improved genotypes from IITA, Burkina Faso and INRAN (Table 1). Varieties IT93K-693-2, IT99K-573-1-1 and IT98K-205-8 were used as resistant checks; 
TABLE 1. Cowpea germplasm screened for the resistance to Striga gesnerioides, origin and seed colour, in Niger in 2012

\begin{tabular}{|c|c|c|c|c|c|c|c|}
\hline $\mathrm{N}^{\mathrm{o}}$ & Name & Origin & Colour & $\mathrm{N}^{\mathrm{o}}$ & Name & Origin & Colour \\
\hline 1 & TN $121-80$ & Niger & Wh & 26 & B6/15/2367-58 & Niger & Mo \\
\hline 2 & IT99K-573-1-1 & IITA & Wh & 27 & B5/11/2492 & Niger & Wh \\
\hline 3 & TN5-78 & Niger & $\mathrm{Br}$ & 28 & $2450-132(\mathrm{sac})$ & Niger & Wh \\
\hline 4 & TN88-63 & Niger & Wh & 29 & B5/13/2374-156 & Niger & Wh \\
\hline 5 & KVx30-309-6G & B. Faso & Wh & 30 & B3/9/2526-200 & Niger & $\mathrm{Br}$ \\
\hline 6 & Suvita-2 & B. Faso & $\mathrm{Br}$ & 31 & 2409 (Etq) & Niger & Wh \\
\hline 7 & IT93K-693-2 & IITA & $\mathrm{Br}$ & 32 & B1/16/2470-152 & Niger & $\mathrm{Br}$ \\
\hline 8 & HTR & Niger & Wh & 33 & IT90K-372-1-2 & IITA & Wh \\
\hline 9 & KVx771-10G & B. Faso & Wh & 34 & TN27-80 & Niger & Wh \\
\hline 10 & $2354(\mathrm{Etq})$ & Niger & Wh & 35 & IT98K-205-8 & Niger & Wh \\
\hline 11 & $\mathrm{~B} 3 / 13 / 2399-81 \mathrm{~A}(1)$ & Niger & Wh & 36 & 2472-154(Sac) & Niger & $\mathrm{Wh}$ \\
\hline 12 & B5/15/2627 (2eR) & Niger & Wh & 37 & B1/1/2409-91 (1) & Niger & Wh \\
\hline 13 & $2505(\mathrm{sac})$ & Niger & Wh & 38 & $\mathrm{~B} 1 / 6 / 2356-38$ & Niger & Wh \\
\hline 14 & $2326(\mathrm{sac})$ & Niger & Wh & 39 & $2432(\mathrm{Etq})$ & Niger & Mo \\
\hline 15 & $2462-144(\mathrm{sac})$ & Niger & Wh & 40 & B4/1/2381-63 (2eR) & Niger & Wh \\
\hline 16 & $\mathrm{~B} 4 / 9 / 2610(2 \mathrm{eR})$ & Niger & Wh & 41 & B3/18/2381-63 & Niger & Wh \\
\hline 17 & B3/17/2458-140(2) & Niger & $\mathrm{Br}$ & 42 & B2/16/2378 (1ereR) & Niger & Wh \\
\hline 18 & $2458-140(\mathrm{sac})$ & Niger & $\mathrm{Br}$ & 43 & $2491-171(\mathrm{Etq})$ & Niger & $\mathrm{Br}$ \\
\hline 19 & $\mathrm{~B} 6 / 3 / 392-74$ & Niger & $\mathrm{Wh}$ & 44 & $2510-192$ (Etq) & Niger & Wh \\
\hline 20 & $2367-58(\mathrm{sac})$ & Niger & Wh & 45 & $2649-151$ (Etq) & Niger & Wh \\
\hline 21 & B4/2/2491-171 & Niger & $\mathrm{Br}$ & 46 & B3/20/2323 2R & Niger & Wh \\
\hline 22 & $2374-56(\mathrm{sac})$ & Niger & Wh & 47 & $\mathrm{~B} 1 / 12 / 2525-234$ & Niger & Wh \\
\hline 23 & $2429-111$ (sac) & Niger & Wh & 48 & $2372-54(\mathrm{sac})$ & Niger & Wh \\
\hline 24 & $2598(\mathrm{Etq})$ & Niger & Wh & 49 & B5/19/2410-92 & Niger & Wh \\
\hline 25 & B1/9/2320-02 & Niger & Wh & 50 & $\mathrm{~B} 1 / 5 / 23542 \mathrm{R}$ & Niger & Wh \\
\hline 51 & $2383(\mathrm{Etq})$ & Niger & Wh & 66 & B1/4/2413-95 & Niger & Wh \\
\hline 52 & B6/14/2472-154 & Niger & Wh & 67 & $\mathrm{~B} 2 / 12 / 2472-150$ & Niger & Mo \\
\hline 53 & $2610(\mathrm{Etq})$ & Niger & Wh & 68 & 2432-144(Etq) & Niger & $\mathrm{Wh}$ \\
\hline 54 & B4/8/2436-118 & Niger & Wh & 69 & B3/4/2507 (2eR) & Niger & Wh \\
\hline 55 & $\mathrm{~B} 4 / 7 / 2338-20(2 \mathrm{eR})$ & Niger & Wh & 70 & $\mathrm{~B} 6 / 2 / 2516$ & Niger & Wh \\
\hline 56 & $2504-186(\mathrm{Etq})$ & Niger & Wh & 71 & 2491-191 (Sac) & Niger & $\mathrm{Br}$ \\
\hline 57 & $2420-102$ (sac) & Niger & Wh & 72 & $\mathrm{~B} 1 / 18 / 2542(2 \mathrm{e} \mathrm{R})$ & Niger & Wh \\
\hline 58 & 2431-113 (Etq) & Niger & Wh & 73 & $2400-822 \mathrm{R}$ & Niger & Wh \\
\hline 59 & $2390-72(\mathrm{Sac})$ & Niger & Wh & 74 & $2326($ Etq $)$ & Niger & Wh \\
\hline 60 & $2392-74($ Etq $)$ & Niger & $\mathrm{Wh}$ & 75 & B3/3/2350-32(1) & Niger & $\mathrm{Wh}$ \\
\hline 61 & B1/13/2614-296(2e R) & Niger & Wh & 76 & B4/13/2563-245 1R & Niger & Wh \\
\hline 62 & B5/12/2462-144(2eR) & Niger & $\mathrm{Wh}$ & 77 & B2/19/2405-87 (2e R) & Niger & $\mathrm{Wh}$ \\
\hline 63 & $\mathrm{~B} 3 / 18 / 2525-30$ & Niger & Wh & 78 & B1/14/2473-155 & Niger & Wh \\
\hline 64 & B4/14/2343-25(1) & Niger & Wh & 79 & 2477-152(Etq) & Niger & $\mathrm{Br}$ \\
\hline 65 & B2/10/2457-119 & Niger & Wh & 80 & 2427 (Etq) & Niger & $\mathrm{Br}$ \\
\hline
\end{tabular}

$\mathrm{Wh}=$ white; $\mathrm{Br}=$ brown; $\mathrm{Mo}=$ mottle; $\mathrm{B}=$ Faso: Burkina Faso 
while the varieties TN88-63, TN27-80 and IT90K-372-1-2 were included as susceptible checks.

Experimental procedure. The study was conducted under natural infestation, in fields that were severely infested with $S$. gesnerioides. The experiment was carried out under rainfed conditions in 2012, at Maradi Station $\left(13^{\circ} \quad 28^{\prime} \mathrm{N}\right.$ latitude and $7^{\circ} 10^{\prime} \mathrm{E}$ longitude) in the Sudano Sahelian zone, in Niger. The experimental set up was a $4 \times 20 \alpha$ lattice design, with three replications. Each plot comprised of two rows each $3 \mathrm{~m}$ long, with plants spaced at 0.80 and $0.50 \mathrm{~m}$.

Three seeds were planted per hill, and were thinned to one per hill two weeks after emergence. Super single phosphate (SSP) fertiliser was applied at a rate of $100 \mathrm{~kg}^{-1}$ per hectare, one week before sowing. Two hoeweedings were done before Striga emergence. An insecticide, dimethoate $\left(\mathrm{C}_{5} \mathrm{H}_{12} \mathrm{NO}_{3} \mathrm{PS}_{2}\right)$ was applied at pre-flowering, flowering and after pod formation to control insects at a rate of 1 $\mathrm{L} \mathrm{ha}^{-1}$.

Data collection and analysis. Data were collected on number of days from planting to flowering (DFL); number of days from planting to $50 \%$ flowering (50\% FL); Striga shoots per plot (SSP). Striga shoots were counted nine weeks after planting (WAP). Striga density (DS) was latter computed as the number of emerged Striga shoots per plot divided by plot area. Striga dry biomass (SDB) was also measured by weighing all the dried Striga shoots from each plot. Cowpea pod dry weight $(\mathrm{PW})$ was measured by weighing oven dried $\left(100{ }^{\circ} \mathrm{C}\right.$ for $\left.8 \mathrm{hrs}\right)$ pods from whole plots. Grain yield (GY) was estimated to $\mathrm{kg}$ $\mathrm{ha}^{-1}$ from weight of seeds obtained per plot. One hundred (100) seed weight (100-SW) was calculated from 100 dry seeds randomly taken from each plot. Fodder yield (FY) was obtained by drying and weighing stems and leaves left after pods were harvested in each plot.
The genotypes were classified as resistant or susceptible using a scale described by Singh and Emechebe (1997) as follows: 1. Resistant $=$ no Striga emergence in a plot and no Striga symptom observed on plants; 2 . Moderately resistant: few Striga emergence (2-3) per plot but no Striga symptoms observed; 3. Tolerant: Several Striga emergences but no significant yield reduction; and 4. Susceptible $=5$ to several Striga plant emerged per plot and plants show severe Striga symptoms. All the data obtained from the trial were subjected to analysis of variance (ANOVA) using PROC GLM in SAS 9.3.

Pearson's correlation coefficients were used to test correlations among the following measured traits 50\%FL, DS, SDB, GY, 100SW and PW using SAS (SAS 9.3). Principal component analysis (PCA) and cluster analysis using the same software were then performed.

\section{RESULTS}

There were significant differences $(\mathrm{P}<0.0001)$ among the genotypes for all the traits measured (Table 2).

The means of flowering dates, Striga density (DS) and dry biomass (SDB), grain yield (GY), 100-seed weight (100-SW) and pod weight $(\mathrm{PW})$ are presented in Table 3.

The number of days to $50 \%$ flowering varied from 49 to 73 days, with a mean of 59 days. The number of days to $50 \%$ flowering was highest in B5/15/2627 2R (73 days) and lowest in IT98K-205-8 (49 days).

The three resistant checks (IT93K-693-2, IT99K-573-1-1 and IT98K-205-8) had no emerged Striga shoots. Striga shoots was low in lines 2491-171, 2472-154 and Suvita-2, with mean values of $0.43,0.74$ and 0.87 , respectively. These values were significantly different from those of the susceptible check, IT90K-372-1-2 (7.84 Striga shoots $\mathrm{m}^{-2}$ ). Varieties 2491-171, 2472-154 and Suvita-2 were categorised as moderately resistant. Eight lines (B2/16/2378, B1/13/2614-296, B1/ 4/2413-95, B2/19/2405-87, B1/18/2542, B4/ 
TABLE 2. Summary of analysis of variance (ANOVA) table for effect of cowpea genotype on selected parameters at Maradi, Niger

\begin{tabular}{|c|c|c|c|c|c|c|c|}
\hline $\begin{array}{l}\text { Sources of } \\
\text { variance }\end{array}$ & DF & $50 \%$ & DS & SDB & GY & PW & 100-SW \\
\hline Blocks (Rep) & 9 & 13.67 & 9.68 & 86.82 & 22893.85 & 13072.69 & 0.78 \\
\hline Treatments & 79 & $62.42^{*}$ & $13.01 *$ & $332.44 *$ & $59224.66 *$ & $33497.39 *$ & $16.90 *$ \\
\hline Error & 149 & 10.90 & 5.37 & 145.95 & 14718.74 & 10242.81 & 0.79 \\
\hline Total & 239 & & & & & & \\
\hline
\end{tabular}

$(*)=$ Significant at 0.0001 probability level; $50 \% \mathrm{FL}=50 \%$ flowering $; \mathrm{DS}=$ Striga density $; \mathrm{SDB}=$ Striga density biomass; GY = Grain yield; PW = Pod dry weight; 100-SW = 100 seed weight

7/2338-20, B1/12/2525-234, and B3/13/239981A) described as tolerant had high DS (2.53 to 8.77 Striga shoots $\left.\mathrm{m}^{-2}\right)$, but no significant yield losses. Ten susceptible lines (B4/13/2563245 1R, IT90K-372-1-2, B5/15/2627 2R, B1/ 14/2473-155, B6/2/2516, B2/10/2457-119, B3/ $3 / 2350-32$, B3/18/2381-63, 2505 and 2510192) had low to high number of emerged Striga (1.36 to 8.27 shootsm $^{-2}$ ).

Cowpea grain yield varied from $54.88 \mathrm{~kg}$ $\mathrm{ha}^{-1}$ for line $2510-192$, to $691.67 \mathrm{~kg}$. ha ${ }^{-1}$ for line B1/18/2542 with an average yield of $246.12 \mathrm{~kg} \mathrm{ha}^{-1}$. Only five genotypes $(6 \%)$ had yield exceeding $500 \mathrm{~kg} \mathrm{ha}^{-1}$; while 35 (44\%) had yield less than $200 \mathrm{~kg} \mathrm{ha}^{-1}$. Yield reductions were significantly high (79 and 66\%) in the susceptible cowpea lines, compared to tolerant and resistant lines. In contrast, it was observed that yield of tolerant cultivars (441.17 to $691.67 \mathrm{~kg} \mathrm{ha}^{-1}$ ) was higher than that of the resistant lines (276.63 to $\left.380 \mathrm{~kg} \mathrm{ha}^{-1}\right)$. Striga dry biomass varied from 0.00 (IT93K-693-2, IT99K-573-1-1 and IT98K-205-8) to $52.88 \mathrm{~g}$ (B6/2/2516). The overall genotype mean for SDB was 17.91 per plot.

One hundred cowpea seed weight (100$\mathrm{SW})$ varied from $7.3 \mathrm{~g}(2512-192)$ to $22.25 \mathrm{~g}$ (B4/13/2563-245 1R), with a mean of 14.91 g. Cowpea pod weight ranged from $50.93 \mathrm{~g}$ (2429-111) to $548.07 \mathrm{~g}$ (B1/18/2542 2R) with an average of $195.52 \mathrm{~g}$ per plot.
Correlation studies. Table 4 shows correlation coefficients for Striga density and dry biomass on yield and yield components. Striga density and SDB were not correlated $(\mathrm{P}>0.05)$ with yield and yield components. However, Striga density was positively and significantly $(\mathrm{P}<0.05)$ correlated with SDB $(\mathrm{r}=0.78)$ and PW $(\mathrm{r}=0.91)$ (Table 4).

Principal component analysis. The first two principal component (PCs) or latent correlation matrices with coefficient values (Eigenvalues) greater than 1.0 are presented in Table 5 together with the percentage of total variability accounted for by each component, and the cumulative percentages. The first two components accounted for $69.68 \%$ of the total variance (Table 5). The first PC accounted for $35.48 \%$; whereas the second accounted for $34.19 \%$.

The identification of the components may be achieved by examination of the latent vectors (eigenvectors) for these principal components, but with emphasis on the first two principal components. The first PC with reference to its high value (Table 6), was positively associated with pod weight (PW) and grain yield. The second PC was associated with Striga dry biomass (SDB), Striga density (DS) and grain yield (GY). 
TABLE 3. Striga density and dry biomass, yield and yield components of cowpea germplasm screened at Maradi in Niger

\begin{tabular}{|c|c|c|c|c|c|c|}
\hline Genotypes & $\begin{array}{c}50 \% \text { FL } \\
\text { (days) }\end{array}$ & $\begin{array}{c}\mathrm{DS} \\
\left(\text { shoot } \mathrm{m}^{-2}\right)\end{array}$ & $\mathrm{SDB}(\mathrm{g})$ & $\begin{array}{c}\text { GY } \\
\left(\mathrm{kg} \mathrm{ha}^{-1}\right)\end{array}$ & $\begin{array}{c}10-S W \\
(\mathrm{~g})\end{array}$ & PW (g) \\
\hline \multicolumn{7}{|l|}{ Resistant checks } \\
\hline IT93K-693-2 & 54.00 & 0.00 & 0.00 & 380.00 & 15.55 & 268.40 \\
\hline IT99K-573-1-1 & 50.33 & 0.00 & 0.00 & 340.74 & 17.70 & 170.27 \\
\hline IT98K-205-8 & 49.00 & 0.00 & 0.00 & 276.63 & 15.10 & 248.20 \\
\hline \multicolumn{7}{|l|}{ Moderately resistant } \\
\hline $2491-171$ & 58.67 & 0.43 & 4.00 & 258.15 & 16.80 & 182.67 \\
\hline $2472-154$ & 57.00 & 0.74 & 4.45 & 141.73 & 16.35 & 158.67 \\
\hline Suvita-2 & 63.67 & 0.87 & 6.70 & 244.75 & 16.75 & 178.17 \\
\hline \multicolumn{7}{|l|}{ Tolerant to Striga } \\
\hline $\mathrm{B} 2 / 16 / 2378$ & 61.33 & 8.77 & 49.73 & 502.78 & 13.80 & 393.10 \\
\hline B1/13/2614-296 & 60.00 & 5.37 & 23.30 & 477.16 & 15.55 & 263.27 \\
\hline B1/4/2413-95 & 59.00 & 5.06 & 21.60 & 441.17 & 14.75 & 347.73 \\
\hline B2/19/2405-87 & 58.00 & 4.5 & 28.53 & 476.79 & 15.45 & 333.07 \\
\hline B1/18/2542(2eR) & 62.67 & 3.52 & 16.70 & 691.67 & 17.65 & 548.07 \\
\hline B4/7/2338-20 (2eR) & 61.67 & 3.46 & 20.40 & 561.79 & 14.50 & 462.43 \\
\hline $\mathrm{B} 1 / 12 / 2525-234$ & 60.00 & 2.84 & 28.60 & 671.05 & 15.10 & 521.47 \\
\hline B3/13/2399-81 A(1) & 63.00 & 2.53 & 11.47 & 573.21 & 17.10 & 458.97 \\
\hline \multicolumn{7}{|l|}{ Susceptible checks } \\
\hline IT90K-372-1-2 & 57.33 & 7.84 & 25.83 & 150.37 & 15.55 & 111.70 \\
\hline TN88-63 & 61.00 & 3.89 & 18.83 & 230.00 & 12.75 & 131.03 \\
\hline TN27-80 & 59.00 & 1.67 & 19.87 & 170.19 & 15.75 & 170.60 \\
\hline \multicolumn{7}{|l|}{ Ten most susceptible } \\
\hline B4/13/2563-245 1R & 65.33 & 8.27 & 34.70 & 98.27 & 22.25 & 95.47 \\
\hline $\mathrm{B} 5 / 15 / 26272 \mathrm{R}$ & 73.00 & 7.84 & 42.50 & 105.62 & 17.85 & 91.17 \\
\hline B1/14/2473-155 & 61.00 & 7.53 & 34.13 & 194.26 & 14.40 & 158.17 \\
\hline $\mathrm{B} 6 / 2 / 2516$ & 71.33 & 6.42 & 31.00 & 80.93 & 17.60 & 68.70 \\
\hline B2/10/2457-119 & 56.00 & 6.17 & 29.56 & 190.43 & 11.95 & 169.77 \\
\hline B3/3/2350-32 & 67.67 & 6.05 & 29.167 & 163.4 & 14.1 & 151.8 \\
\hline B3/18/2381-63 & 61.33 & 5.43 & 30.16 & 82.90 & 14.95 & 79.43 \\
\hline 2505 & 63.33 & 5.37 & 20.73 & 72.41 & 11.5 & 56.90 \\
\hline 2429-111 (sac) & 57.33 & 1.36 & 24.63 & 66.67 & 11.65 & 50.93 \\
\hline $2510-192$ & 58.67 & 3.52 & 19.1 & 54.88 & 7.3 & 62.67 \\
\hline Mean & 59.4 & 3.37 & 17.91 & 246.12 & 14.91 & 195.52 \\
\hline $\mathrm{LSD}(\mathrm{P}<0.05)$ & 5.34 & 3.75 & 19.39 & 193.68 & 1.44 & 156.65 \\
\hline CV\% $\%(5 \%)$ & 5.58 & 69.04 & 67.10 & 50.06 & 6.01 & 51.46 \\
\hline
\end{tabular}

$\mathrm{CV}=$ Coefficient of variation $(5 \%) ; \mathrm{LSD}=$ Least Significant Difference at $\mathrm{P}=0.05 ; 50 \% \mathrm{FL}=$ days to $50 \%$ flowering; $\mathrm{DS}=$ Striga density PW = pod weight; $\mathrm{SDB}=$ Strig $a$ dry biomass; $\mathrm{GY}=$ cowpea grain yield; $100-\mathrm{SW}=$ one hundred seeds weight 
TABLE 4. Correlation coefficients of Striga density and dry biomass on yield and yield components

\begin{tabular}{lccllll}
\hline & $50 \% \mathrm{FL}$ & $\mathrm{DS}$ & $\mathrm{PW}$ & SDB & GY & $100-\mathrm{SW}$ \\
\hline $50 \% \mathrm{FL}$ & & & & & & \\
DS & $0.17 \mathrm{NS}$ & & & & \\
PW & $-0.05 \mathrm{NS}$ & $-0.01 \mathrm{NS}$ & & & \\
SDB & $0.18 \mathrm{NS}$ & $0.78^{*}$ & $0.01 \mathrm{NS}$ & & \\
GY & $-0.08 \mathrm{NS}$ & $-0.03 \mathrm{NS}$ & $0.91^{*}$ & $-0.01 \mathrm{NS}$ & & \\
$100-\mathrm{SW}$ & $0.03 \mathrm{NS}$ & $0.006 \mathrm{NS}$ & $0.19 \mathrm{NS}$ & $-0.04 \mathrm{NS}$ & $0.23 \mathrm{NS}$ & \\
\hline
\end{tabular}

$50 \% \mathrm{FL}=$ days to $50 \%$ flowering; $\mathrm{DS}=$ Strigadensity $; \mathrm{Pw}=$ pod weight; SDB = Striga dry biomass; GY $=$ cowpea grain yield; $100-\mathrm{SW}=$ one hundred seeds weight; $(*)$ the correlation coefficients were significant at $\mathrm{P}=0.05 ; \mathrm{NS}=$ the correlation coefficients were not significant

TABLE 5. Eigenvalues of the Correlation Matrix for the principal components associated with traits of cowpea germplasm in Niger

\begin{tabular}{lllll}
\hline & Eigenvalue & Difference & Proportion & Cumulative \\
\hline PC1 & 2.12896842 & 0.07734040 & 0.3548 & 0.3548 \\
PC2 & 2.05162802 & 1.14255976 & 0.3419 & 0.6968 \\
PC3 & 0.90906826 & 0.15078337 & 0.1515 & 0.8483 \\
PC4 & 0.75828490 & 0.64364438 & 0.1264 & 0.9747 \\
PC5 & 0.11464052 & 0.07723063 & 0.0191 & 0.9938 \\
PC6 & 0.03740988 & & 0.0062 & 1.0000 \\
\hline
\end{tabular}

TABLE 6. Eigenvectors from the two principal component axes used to classified cowpea accessions

\begin{tabular}{lcl}
\hline & Prin1 & Prin2 \\
\hline 50\% to flowering & -.247130 & 0.310818 \\
Pod weight & 0.531040 & 0.396442 \\
Striga dry biomass & -.380179 & 0.524134 \\
100 seed weight & 0.268934 & 0.198453 \\
Striga density & -.398485 & 0.514312 \\
Grain yield & 0.530350 & 0.409400 \\
\hline
\end{tabular}


Cluster analysis. The agglomerative accessions) and cluster $\mathrm{C}$ (56 accessions). hierarchical clustering dendrogram (Fig. 1) Cluster A included high yielding and Striga illustrated the relationship among the 80 accessions based on the traits that contributed most to the first two (2) principal components (Table 6). Three main clusters were identified: cluster A (4 accessions), cluster B (20 tolerant varieties; while Cluster B included intermediate yielding and resistant varieties. Cluster C had the low-yielding and Striga susceptible lines.

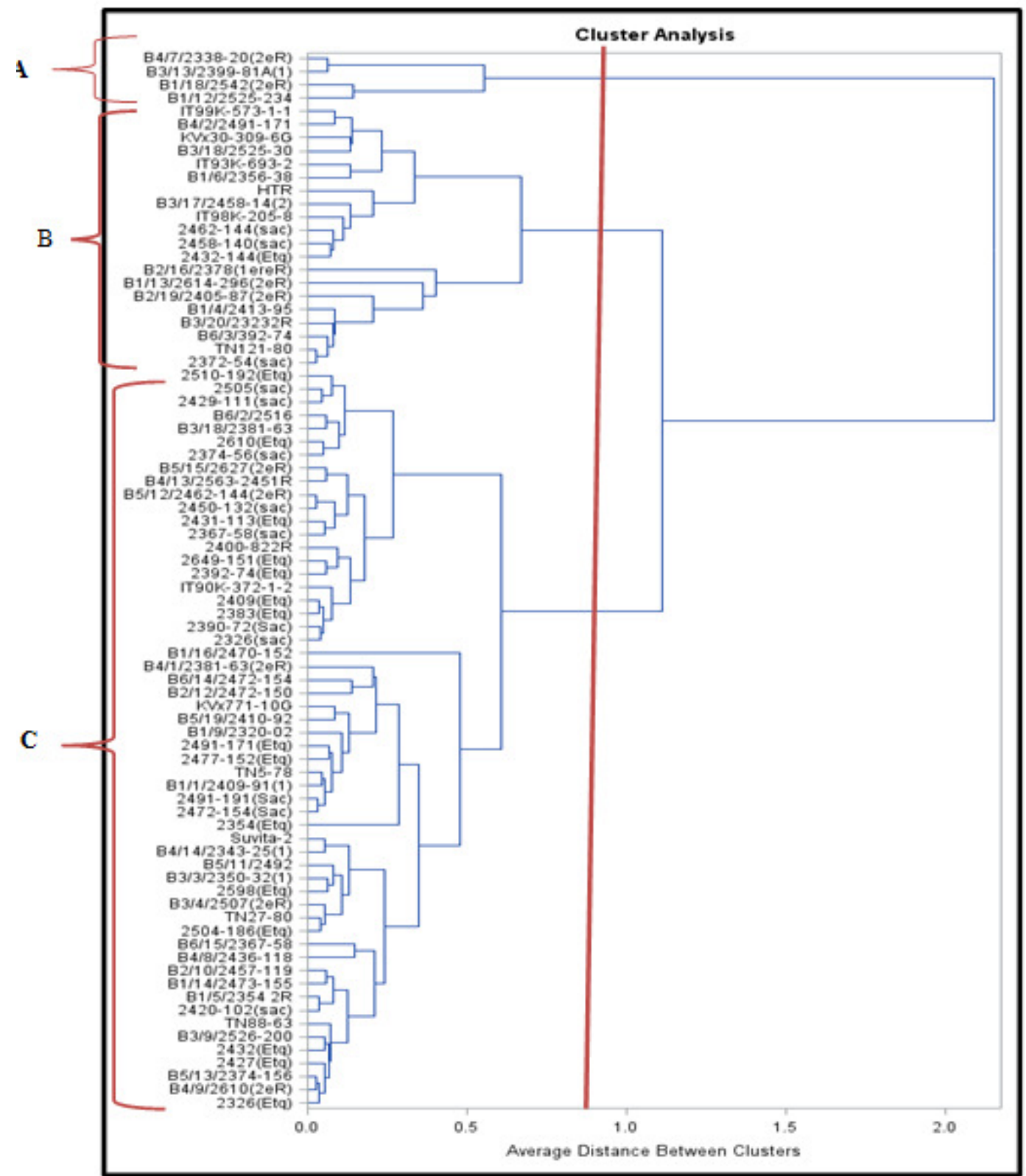

Figure 1. Dendrogram constructed based on yield and Striga resistance parameters of cowpea. 


\section{DISCUSSION}

There was variation in the number of days to $50 \%$ flowering among the genotypes (Table $3)$. This variability may be due to climatic conditions or the genetic background of the varieties. In this study the number of days to $50 \%$ flowering ranged from 49 to 73 days after planting with a mean of 59.4. This showed that there were no extra early maturing varieties in the germplasm screened. Early maturity is one of the major criteria for choosing cowpea varieties highlighted by farmers during the participatory rapid appraisal (PRA). Therefore, it is an important breeding goal in the country.

Developing early maturing cowpea varieties in Niger requires introduction of exotic material or screening for earliness in germplasm.

Only three genotypes (IT93K-693-2, IT99K-573-1-1 and IT98K-205-8), included as resistant checks, were free from Striga infestation in this study. The resistance in IT93K-693-2 confirmed the results of Singh (2002) and Boukar et al. (2004a), who reported that this genotype was resistant to all the five known Striga races in Africa. Recently, Tignegre (2010) found similar results with the races prevailing in Burkina Faso. The resistance observed in IT99K-573-1-1 and IT98K-205-8 is in line with the findings of Tchiagam et al. (2010), that no Striga emerged from the two genotypes screened for the resistance to race 5 in Cameroon. Though, these genotypes have demonstrated high resistance to Striga in this study, their grain yields were very low, compared to their yields obtained from studies in Cameroon and in Burkina Faso. IT99K-573-1-1 and IT98K-2058 yielded 1042.75 and $871.10 \mathrm{~kg} \mathrm{ha}^{-1}$, respectively in Cameroon versus 340.74 and $276.63 \mathrm{~kg} \mathrm{ha}^{-1}$ in Niger, respectively. Line IT93K-693-2 yielded $911.60 \mathrm{~kg} \mathrm{ha}^{-1}$ in Burkina Faso versus only $380 \mathrm{~kg} \mathrm{ha}^{-1}$ in this study. The differences observed may be attributed to genotypic response to climatic conditions and soil types. The genotypes are well adapted to conditions in Cameroon. In Cameroon, the study was conducted in the Sudano-Sahelian belt with ferruginous vertisol, and an average annual rainfall ranging from $800-900 \mathrm{~mm}$. The soil is sandy clay, with $8.2 \mathrm{mg} \mathrm{kg}$ organic matter and $\mathrm{pH}$ 5.65.

In Burkina Faso, the experiment was conducted on station, where the average annual rainfall was $1131 \mathrm{~mm}$. Rainfall at Maradi is about $480 \mathrm{~mm}$ and the soil is ferruginous tropical, with a $\mathrm{pH}$ of 6.5. This soil contains $12 \%$ clay, $5 \%$ loam, $4 \%$ coarse silt, $77 \%$ sand and $2 \%$ organic matter (Raynaut et al., 1984). This probably explains the difference in yield observed in the different experiments with the same varieties.

Resistant lines in this present study had lower yield compared to the tolerant lines. Although this is the case, but can be exploited in breeding for resistance to Striga cowpea as donor parents.

In contrast, some genotypes such as B2/ $16 / 2378, B 1 / 18 / 2542$ and B1/12/2525-234 supported a high number of Striga shoots, but performed well for yield, indicating that they are tolerant to Striga. These lines are potential sources for breeding for high yield in cowpea.

Out of the susceptible lines, six genotypes gave a significantly lower yield, compared to the weakest susceptible control (IT90K-3721-2); suggesting that they were highly susceptible to Striga. The high number of genotypes for which the yield was less than $200 \mathrm{~kg} \mathrm{ha}^{-1}$ indicates the inherent low yield of landraces in Niger.

There were no significant correlations between yield components and Striga emergence parameters (Table 4). This result is inconsistent with the findings of Kamara $e t$ al. (2008) in which they reported that yield components were negatively correlated with Striga count. Tignegre (2010), Omoigui et al. (2012) and Ekeleme et al.(2013) also reported negative correlations between these characters. This shows that Striga has a high impact on yield in cowpea. This, however, is not true with tolerant genotypes where high infestation still resulted into high yields. Further some 
genotypes with the smallest Striga population recorded some of the lowest yields.

Information from principal component analyses may guide plant breeders in making selected crosses in a selection programme. The results in this study reveal that out of six parameters used, only four contributed significantly to the variability observed among the genotypes.

Cluster analysis grouped the genotypes into three main clusters: A, B and C. Cluster A was composed of four accessions (B4/7/2338-20 (2eR), B3/13/2399-81 A (1), B1/18/2542 (2eR) and $\mathrm{B} 1 / 12 / 2525-234)$ that were the top yielding and tolerant to Striga. The yield of these accessions exceeded $550 \mathrm{~kg} \mathrm{ha}^{-1}$. This cluster can be further divided into two sub-clusters of 2 accessions each according to yield. Subcluster A1 includes genotypes B1/18/2542 (2eR) and B1/12/2525-234 with a yield exceeding $670 \mathrm{~kg} \mathrm{ha}^{-1}$. These can be used as donor parents in breeding for high yield in environments where Striga is not a constraint to cowpea production. Tolerant genotypes are discouraged in Striga infested areas as they increase seed bank in the soil. Sub-cluster A2 comprises genotypes B4/7/2338-20 (2eR) and B3/13/2399-81 A (1) with a yield exceeding $560 \mathrm{~kg}$. ha ${ }^{-1}$. Cluster B has genotypes that are moderately yielding and resistant to Striga. This cluster too, can be divided into two subclusters. B1 comprises genotypes: IT99K-5731-1, B4/2/2491-171, KVx30-309-6G, B3/18/ 2525-30, IT93K-693-2, B1/6/2356-38, HTR, B3/17/2458-14 (2), IT98K-205-8, 2462-144 (sac), 2458-140 (sac) and 2432-144 (Etq). On the other hand, sub-cluster B2 included genotypes B2/16/2378 (1ereR), B1/13/2614296 (2eR), B2/19/2405-87 (2eR), B1/4/241395, B3/20/2323 2R, B6/3/392-74, TN121-80 and 2372-54 (sac). Five genotypes classified as tolerant, with high yields and some Striga susceptible varieties were grouped in this cluster; meaning that yield parameter contributed greatly in discriminating the genotypes. This was revealed by its high contribution to the first two principal components. Cluster $\mathrm{C}$ was composed of the low-yielding and most of the susceptible genotypes. Cluster $\mathrm{C}$ can also be partitioned in three sub-clusters according to yield. The sub-cluster C1 included genotypes 2510192(Etq), 2505(sac), B6/2/2516, B3/18/238163, 2610(Etq), 2374-56 (sac), B5/15/2627 (2eR), B4/13/2563-2451R, B5/12/2462-144 (2eR), 2450-132 (sac), 2431-113 (Etq), 236758 (sac), 2400-822R, 2649-151 (Etq), 239274 (Etq), IT90-372-1-2, 2409 (Etq), 2383 (Etq), 2370-72 (sac) and 2326 (sac). Subcluster C2 comprises genotypes B1/16/2470152, B4/1/2381-63 (2eR), B6/14/2472-154, B2/12//2472-154, B2/12/2472-150, KVx77110G, B5/19/2410-92, B1/9/2320-02, 2491-171 (Etq), 2477-152 (Etq), TN5-78, B1/1/240991 (1), 2491-191 (sac), 2472-154 (sac) and 2354 (Etq). Sub-cluster C3 is composed of genotypes Suvita2, B4/14/2343-25 (1), B5/11/ 2492, B3/3/2350-32(1), 2598 (Etq), B3/4/ 2507(2eR), TN27-80, 2504-186 (Etq), B6/15/ 2367-58, B4/8/2436-118, B2/10/2457-119, B1/ 14/2473-155, B1/5/2354 2R, 2420-102 (sac), TN88-63, B3/9/2526-200, 2432 (Etq), 2427 (Etq), B5/13/2374-156, B4/9/2610 (2eR) and 2326 (Etq). The moderately resistant genotypes, 2491-171, 2472-154 and Suvita-2 were grouped in this cluster because of their low yield. The above shows that there is genotypic variability between cowpea accessions in this present study, implying that they can be employed in improving the crop for resistance to Striga and yield.

\section{CONCLUSION}

New sources of Striga resistance were not found in the accessions studied. However, genotypes IT93K-693-2, IT99K-573-1-1 and IT98K-205-8 were confirmed as good sources of Striga resistance genes. Cultivars B2/16/ 2378, B1/18/2542 and B1/12/2525-234 are candidates for improving yield. The best combination of crosses to incorporate Striga resistance into adapted lines would be IT93K693-2 as donor parent and the top three 
farmers' preferred varieties i.e, KVx30-3096G, IT90K-372-1-2 and TN5-78. The hierarchical analysis grouped the genotypes screened in tolerant and high yielding, resistant and intermediate yielding and susceptible and low yielding.

\section{ACKNOWLEDGEMENT}

We acknowledge Alliance for a Green Revolution in Africa for the financial support to this research.

\section{REFERENCES}

Atokple, I., Singh, B. and Emechebe, A. 1993. Independent inheritance of Striga and Alectra resistance in cowpea genotype B30. Crop Science 33:714-715.

Atokple, I., Singh, B. and Emechebe, A. 1995. Genetics of resistance to Striga and Alectra in cowpea. Journal of Heredity 86:45-49.

Botanga, C.J. and Timko, M.P. 2006. Phenetic relationships among different races of Striga gesnerioides (Willd.) Vatke from West Africa. Genome 49:1351-1365.

Boukar, O., Kong, L., Singh, B., Murdock, L. and Ohm, H. 2004. AFLP and AFLPderived SCAR markers associated with resistance in cowpea. Crop Science 44: 1259-1264.

Cardwell, K. and Lane, J. 1995. Effect of soils, cropping system and host phenotype on incidence and severity of Striga gesnerioides on cowpea in West Africa. Agriculture, Ecosystems \& Environment 53: 253-262.

Egbe, O., Alibo, S. and Nwueze, I. 2010. Evaluation of some extra-early-and earlymaturing cowpea varieties for intercropping with maize in southern Guinea Savanna of Nigeria. Agricultural and Biology Journal of North America 1:845858.

Ehlers, J.D. and Hall, A.E. 1997. Cowpea (Vigna unguiculata L. Walp.). Field Crops Research 53:187-204.
Ekeleme, F., Jibrin, J., Kamara, A., Oluoch, M., Tofa, I., Solomon, R. and Kadafur, M. 2013. Level and extension of Striga infestation of maize and cowpea crops in Bauchi and Kano states, Nigeria. Biophysical Baseline Survey, International Institute of Tropical Agriculture, Ibadan, Nigeria. 41pp.

Ekpo, I.A., Agbor, R.B., Osuagwu, A.N., Okpako, E.C. and Ekanem, B.E. 2012. Evaluation of Eight Cowpea (Vigna unguiculata $\mathrm{L}$. Walp) species for yield and associated traits. Journal of Pure and Applied Sciences and Technology 12: 1-7.

Emechebe, A., Singh, B., Leleji, O., Atokple, I. and Adu, J. 1991. Cowpea Striga problems and research in Nigeria. Combating Striga in Africa. Kim, S.K. (Ed.). IITA, Ibadan, Nigeria. 18-28.

Kamara, A.Y., Chikoye, D., Ekeleme, F., Omoigui, L.O. and Dugje, I. Y. 2008. Field performance of improved cowpea varieties under conditions of natural infestation by the parasitic weed Striga gesnerioides. International Journal of Pest Management 54:189-195.

Karuri, H.W., Ateka, E.M., Amata, R., Nyende, A.B., Tmuigai, A.W., Mwasame, E. and Gichuki, S.T. 2010. Evaluating diversity among Kenyan sweet potato genotypes using morphologicaand SSR markers. International Journal of Agricultural Biology 12:33-38.

Lane, J., Moore, T., Child, D. and Cardwell, K. 1996. Characterization of virulence and geographic distribution of Striga gesnerioides on cowpea in West Africa. Plant Disease 80:299-301.

Nkongolo, K.K. 2003. Genetic characterization of Malawian cowpea (Vigna unguiculata (L.) Walp) landraces. Diversity and gene flow among accessions. Euphytica 129: 219-228.

Omoigui, L., Kamara, A., Ishiyaku, M. and Boukar, O. 2011. Comparative responses of cowpea breeding lines to Striga and Alectra in the dry savanna of northeast 
Nigeria. African Journal of Agricultural Research 7:747-754.

Raynaut, C., Koechlin, J., Basset, P., Cheung, C. and Stigliano, M. 1984. Le développement rural de la Région de Maradi: Analyser et comprendre la diversité. GRID, Université de Toulouse. $174 \mathrm{pp}$.

Singh, B. and Emechebe, A. 1990. Inheritance of Striga resistance in cowpea genotype B301. Crop Science 30:879.

Singh, B.B. and Emechebe, A.M. 1997. Advances in research on cowpea Striga and Alectra. Advances in Cowpea Research 215-224.

Singh, B.B. 2002. Breeding cowpea varieties for resistance to Striga gesnerioides and Alectra vogelii. Challenges and Opportunities for Enhancing Sustainable Cowpea Production 154-163.
Tchiagam, J.B.N., Bell, J.M., Birwe, S.G., Gonne, S. and Youmbi, E. 2010. Varietal response of cowpea (Vigna unguiculata (L.) Walp.) to Striga gesnerioides (Willd.) Vatke race SG5 infestation. Notulae Botanicae Horti Agrobotanici Cluj-Napoca 38:33-41.

Tignegre, J.B.D.L.S. 2010. Genetic study of cowpea (Vigna unguiculata (L.) Walp) resistance to Striga gesnerioides (Willd.) vatke in Burkina Faso. Ph.D. Thesis. University of Kwazulu-Natal, South Africa. $167 \mathrm{pp}$.

Timko, M.P., Ehlers, J.D. and Roberts, P.A. 2007. Cowpea. Pulses, sugar and tuber crops, genome mapping and molecular breeding in plants. 3:49-67. Berlin/ Heidelberg: Springer-Verlag.

Timko, M.P. and Singh, B. 2008. Cowpea, a multifunctional legume. Genomics of Tropical Crop Plants 1:227-258. 